IJLR: International Journal of Law Recontruction

Volume 4, Number 1, April 2020

DOI : http://dx.doi.org/10.26532/ijlr.v4i1.10942

\title{
ANALYSIS OF COVID-19 LOCKDOWN POLICY IMPACT BY THE GOVERNMENT OF THE COUNTRY ON THE ECONOMIC SECTOR AND SIGNING OF WORKING RELATIONSHIPS (LAYOFFS)
}

\author{
Mohammed Abdela Mahammed \\ International Islamic University Malaysia (IIUM), Malaysia \\ gaz126565@gmail.com
}

\begin{abstract}
The lockdown authority based on the laws in each country regarding Health Quarantine is the absolute authority of the Government. As stated, "health quarantine is carried out to prevent and ward off the entry or entry of diseases and / or community health risk factors that have the potential to cause public health emergencies." Therefore if there is a regional government that feels the region has an emergency situation and wants to do a lockdown, of course this is unconstitutional and there needs to be a consul from the regional head with the central government before making any related policies. Considering the emergency situation, the spread of the corona virus which has now infected many people (starting from December 2019 to June 2020) can be categorized as an infectious disease that can trigger public health emergencies, so that the implementation of national quarantine can actually be done especially with authority which is clearly stated in the legislation. But so far the central government has not issued a lockdown policy, even though the number of infections has increased. This is influenced by economic considerations during the lockdown. Economic decline, business failure to the number of layoffs by companies are the main considerations. Likewise, the risk of many workers will be fired (laid off) because the company or office is not operating. Not to mention the government must be able to meet the basic needs of the population during lockdown or national quarantine activities when enacted. The question also arises, whether the government is able to meet the primary needs of its citizens when the lockdown occurs.
\end{abstract}

Keywords: Analysis; COVID-19; Economics; Government; Impact; Layoffs; Lockdown Policy.

\section{A. INTRODUCTION}

It is different from previous economic crises because the pandemic that was most affected was microbusiness. Further incentives are needed on the main strengths of the national economy for economic recovery in microbusiness, tourism and food. In addition, there is also a need for fiscal strengthening as a condition for mitigation and more relaxed monetary policy in the form of credit relaxation and financing for businesses in the main and micro economic sectors. 
In some countries in preventing the spread of the virus imposed lockdown that has been running for nine weeks and stop all economic activity except the provider of basic needs. What makes the difference is that each government's different policies in terms of stimulating funds to micro businesses by giving monthly money and asking large companies to maintain liquidity. Although there is already a guarantee but the demand for public credit here is quite high, and PKB is indeed the most appropriate thing to do, because if it applies a lockdown the government will be overwhelmed to meet the needs of its people. ${ }^{1}$

\section{B. RESULTS AND DISCUSSION}

\section{Legal Aspects of Handling COVID-19Spread}

Health is one of the basic human needs, whose constitutional rights have been guaranteed lately. In fact the constitutional guarantee of the right to health and regulated in the constitution of the laws of each country, namely "The authorities always strive to sincerely promote public hygiene and public health". After the form of a union state, it returns to the form of a unitary state and the coming into force of existing laws and provisions. Correspondingly, the 1948 Constitution of the World Health Organization (WHO) also emphasized that "obtaining the highest degree of health is a human right for everyone" (the enjoyment of the highest attainable standards of health is one of the fundamental rights of every human being) ${ }^{2}$.

The term used is not "human rights", but "fundamental rights", which if we translate into "Basic rights". Then health is affirmed as part of the stated human rights, that: "Every person has the right to live in physical and spiritual prosperity, to live, and to have a good and healthy environment and to have health services." The inclusion of these provisions in the Law illustrates an extraordinary paradigm shift. Health is no longer considered merely a personal matter related to the fate or gift of God that has nothing to do with the responsibility of the state, but rather a legal right that is guaranteed by the state.

The next point is how the Pandemic chronology and the condition response to this problem. It also refers to some facts that occur, or the response that will, and has been done by the government. That there is a very rapid spread of COVID-19 virus and the COVID-19 virus has been declared by WHO as a pandemic, because it has experienced a very rapid increase globally. And, furthermore, the Government determined the Corona virus pandemic or COVID-19 as a national disaster regarding the Determination of Non-Disaster in the Spreading of Corona Virus Disease 2019 (COVID-19) as a National Disaster. And in this regard, the national disaster response caused by the spread of COVID-19 is carried out by the

1 2020. Worldometer. Available:

https://www.worldometers.info/coronavirus/.

2HOROWITZ, CRAJ 2010. The coronavirus is already hurting the world economy. Here's why it could get really scary. CNNBUSINESS, February 10, 2020. 
Task Force for the Acceleration of COVID-19 Handling of each country through synergy between ministries / institutions and local governments. Furthermore, the reaction and determination in which the Governor, regents and mayors as Chairman of the COVID-19 Task Force for the Acceleration of Handling in the regions, in setting policies in their regions must pay attention to the policies of the central government. And the central government must be ready to accept the reaction and the subsequent provisions continue to develop as, Submission by the Governor who submits an application to the Minister of Health to establish PKB in the territory of their respective countries. Which is the current condition, for all of the above, that co-19 as a national disaster and PKB policy will have an impact on the implementation of agreements in various business sectors. in setting policies in their regions, they must pay attention to the policies of the central government. And the central government must be ready to accept the reaction and the subsequent provisions continue to develop as, Submission by the Governor who submits an application to the Minister of Health to establish PKB in the territory of their respective countries. Which is the current condition, for all of the above, that co-19 as a national disaster and PKB policy will have an impact on the implementation of agreements in various business sectors. in setting policies in their regions, they must pay attention to the policies of the central government. And the central government must be ready to accept the reaction and the subsequent provisions continue to develop as, Submission by the Governor who submits an application to the Minister of Health to establish PKB in the territory of their respective countries. Which is the current condition, for all of the above, that COVID-19 as a national disaster and PKB policy will have an impact on the implementation of agreements in various business sectors.

Next is the legal problem that arises as a result of the COVID-19 Pandemic. For example, in the business agreement sector, COVID-19 is the reason for force majeure not to execute the agreement. Or, as a result of conditions that occur that is, business activities globally have received a very large impact due to the outbreak of Corona Virus Disease 19 (COVID$19)^{3}$. Some policies taken by the government can have an impact on disrupted business relations and even have legal implications, it is estimated that many businesses can not carry out agreements as they should, in other words due to COVID-19 this has resulted in delays in the implementation of agreements in various business fields such as banking, implementation of agreements construction and other agreements. Other conditions are, failure to fulfill an agreement or called default, can be justified by law if the

3HUTT, R. 2020. The economic effects of the COVID-19 coronavirus around the world. The World Economic Forum. 
party can prove there are obstacles that can not be avoided or called "force majeure" 4 .

Is this co-19 legal can be used as a reason for the force majeure to not carry out the agreement of course a legal-based explanation is needed. Force Majeure in general. Like the explanation about ${ }^{5}$ :

"The debtor must be punished for reimbursing expenses, losses and interest if he cannot prove that the agreement was not carried out or the timing of the agreement was not due to something unexpected, which could not be insured to him even though there was no bad intention to him"

"There is no reimbursement of costs, losses and interest if due to coercive circumstances or because things happen by chance, the debtor is prevented from giving or doing something that is required, or doing something that is prohibited for him."

Therefore, based on the aforementioned provisions, the main elements that can cause a force majeure situation are an unexpected event, an obstacle that makes an achievement impossible, the inability is not caused by the debtor's error, the inability cannot be risked to the debtor. To be more objective, related to the question whether the corona virus outbreak could be a reason for force majeure not to carry out its obligations, it is necessary to consider the following explanation ${ }^{6}$.

Based on the theory, there are 2 types of force majeure. Absolute Force Majeure is a condition in which the impossibility of the agreement can be carried out and results in the destruction of the promised goods. Relative Force Majeure is a situation where certain circumstances occur that make it difficult for the debtor to carry out the contract. Even if it is carried out, the debtor must make certain sacrifices that make the contract impracticable. Consequently, the execution of the contract can be postponed until the situation ends.

From the various considerations above, it can be concluded as follows. For COVID-19, the applicable category is difficulty, because the parties can still do the work, but it is difficult to carry out due to fear of contracting the virus and the policies. Furthermore, related to the COVID-19 case, the element of Force Majeure has been fulfilled, i.e ${ }^{7}$ :

a. People never know when this will happen (unpredictable).

b. People do not have a contributory effect on the spread of this epidemic.

4 INMAN, P. 2020a. Coronavirus 'could cost global economy \$1.1tn in lost income'. The Guardian, Wed 19 Feb 2020.

5 INMAN, P. 2020b. Will the coronavirus outbreak derail the global economy? The Guardian. International Review of Finance, 10 (1), 1-26.

6 Bagliano, FC, \& Morana, C. (2012). The Great Recession: US dynamics and spillovers to the world economy. Journal of Banking \& Finance, 36 (1), 1-13.

7 Bentolila, S., Jansen, M., \& Jiménez, G. (2018). When credit dries up: Job losses in the great recession. Journal of the European Economic Association, 16 (3), 650-695. 
c. The COVID-19 outbreak was indeed an obstacle in which people could not rule it out.

However, for COVID-19 can be a reason for Force Majeure, then a clear legal or regulatory basis is needed regarding this matter, and in this situation the President may issue a Presidential Decree on the Determination of Non-Disaster Spread of Corona Virus Disease 2019 (COVID-19) as a National Disaster. Basically, the contents of the presidential decree are "Declaring the non-natural disaster caused by the spread of Corona Virus Disease 2019 (COVID-19) as a national disaster".

Thus, this Keppres can be a strong basis for the reasons of force majeure in the implementation of the agreement. And furthermore, for implementation in implementing an agreement, whether the reason for COVID-19 can be used as a reason for Force majeure or force majeure is to return to the agreement in particular and or depends on the definition of force majeure (if any) in the agreement.

Usually the agreement contains 2 (two) types of force majeure clauses, namely non-exclusive clauses, where in this type of clause, conditions that are considered to be force majeure are non-exclusive, so that a party can claim force majeure as long as the conditions agreed to apply force majeure. And, exclusive clauses, which in this type of clause, force majeure is limited to the conditions stated in the agreement. Or in a description of the bias explained that, if in the agreement explicitly stated outbreaks of disease or pandemic as a force majeure event, then the corona / COVID-19 virus outbreak can be used as a reason for force majeure. And, if there isn't or there is a clause stating "other events beyond the ability of the debtor" or the like, then either explicitly or unequivocally stated in the agreement, which must be considered is the achievement, not merely the event and the event was an unexpected event before the agreement was made.

Therefore, regarding whether the COVID-19 pandemic can be considered a force majeure, depends on the force majeure clause contained in the agreement. Concerning the consequences of large-scale social restrictions (PKB) on agreements. Also as an effort to deal with Covid -19 which through a Presidential Decree has been declared a national disaster, then it is followed by the issuance of various local policies from the Governor, regents and or mayors for the implementation of the handling efforts.

The policies taken by the regional government regarding Large-Scale Social Restrictions (PKB) as stipulated in the Governor Regulation of each region regarding the implementation of Large-Scale Social Restrictions in Handling Corona Virus Disease 2019 (COVID-19), are policies taken by the Governor as a form of co-19 national disaster management efforts. And in the current conditions, also can not be denied. Thus the existence of Large- 
Scale Social Restrictions (PKB) policy affects business relationships or agreements that should be implemented, but PKB is a policy that is more specific and applies locally to the local city, so the reason for the existence of the COVID-19 pandemic and the existence of the PKB policy can also be used as a reason for Force Majeure in the agreement ${ }^{8}$.

Related to the regulations that have governed how the implementation of the PKB, As for the restrictions on activities outside the home which are imposed, include, The implementation of learning in schools and / or other educational institutions, Activities of working in the workplace, Religious activities in places of worship, Activities in places or public facilities, Activities social and cultural, and movement of people and goods using modes of transportation. So for this matter, it needs to be reexamined if the party who defaulted on the agreement submits a force majeur because of the existence of COVID-19, then that party must be able to prove that its territory is included in the Large-Scale Social Limitation Area'.

The obligation to stop activities at work or in the office applies to all sectors, except for a few things, there are in the regulations governing the exclusion of temporary suspension of work activities at the office, for offices with several sector categories. Like, all offices of government agencies, both central and regional. Diplomatic representative offices and international organizations, State-Owned Enterprises and Regional-Owned Enterprises (BUMN and BUMD) that participate in handling Corona Virus Diseases (COVID-19) and / or in meeting the basic needs of the community following the arrangements of the relevant ministries and / or provincial government. Businesses engaged in the sector, Health, Food (food and beverage), Energy, Communication and Information Technology, Finance, Logistics, Hospitality, Construction, Strategic Industry. Basic services and public utilities, as well as industries that are designated as national vital objects or certain objects, and the private sector that serves daily needs. Whereas furthermore, the existence of these limitations certainly affects the implementation of the agreement in daily life.

As explained above COVID-19 can be used as a reason for force majeure not to carry out an achievement, but if it is stated in the agreement that the pandemic is not included in the force majeure, then the implementation of the achievement must be carried out even though it is difficult, and must also pay attention to applicable policies. For example, in the construction sector, all workers must be in the work environment, not in and out of the project. Project managers have an obligation to provide a

8 Bezemer, DJ (2011). The credit crisis and recession as a paradigm test. Journal of Economic Issues, 45 (1), 1-18.

9 Jagannathan, R., Kapoor, M., \& Schaumburg, E. (2013). Causes of the great recession of 2007 ?? 2009: The financial crisis was the symptom not the disease. Journal of Financial Intermediation, $22(1), 4-29$. 
place to live, a place to eat and drink, health facilities, so they do not have to leave the construction project site ${ }^{10}$.

That as described above, co-19 can be used as a reason for Force Majeur in the non-implementation of the agreement, and it needs to be reexamined in the relevant agreement specifically how the arrangement is related to the reason for Force Majeure. And, if the agreement is related to Force Majeure, there is a non-exclusive clause, then the party can claim force majeure as long as the conditions agreed to apply force majeure in this case Covid 19 can be the reason for Force Majeure. However, if it is determined otherwise in the agreement that the Pandemic-outbreak does not include the agreed force majeure or the exclusive Force Majeur clause is limited to the conditions stated in the agreement; ${ }^{11}$

Here are some suggestions and steps you can take in this situation:

a. negotiating and / or renewing agreements (addendums) if possible;

b. reviewing the agreement that is in force and identifying the rules related to Force Majeur in the agreement;

c. examine specifically the efforts of the Force Majeure and everything related to the situation including the effort and collection of evidence of force majeure, and the requirements for submitting a request for force majeure if the implementation is interrupted by the COVID-19 effect.

d. If in the drafting of a new agreement, enter the words or provisions regarding infectious diseases / pandemics in the new contract;

e. assess the consequences of non-implementation of the agreement;

f. Collect and retain all documentation relating to the impact of COVID-19 on operations and steps taken in responding to these impacts.

\section{The impact of the COVID-19 global pandemic is very significant for the economy}

The economic slowdown is projected to occur over the next 3-5 months. It could even take longer, because we have not been able to predict when this outbreak can be completely resolved. In the initial phase of this outbreak in each country, the tourism sector, aviation, hospitality, retail and restaurants were immediately hit. Impacts on other sectors will gradually be increasingly felt. This will certainly have an impact on the fate of workers. Even though President has asked employers not to make Termination of Employment (PHK), but this option is feared will still be pursued in the face of the current crisis $^{12}$.

10 Larry Elliot, L. (2020). Prepare for the coronavirus global recession. The Guardian. Media report. at SSRN 3500921

11 El-Erian, M. (2020). The Coming Coronavirus Recession and the Uncharted Territory Beyond. Foreign Affairs, Media Report. Available at:https://www.foreignaffairs.com/articles/2020-03- 17 / coming-coronavirus-recession

12 Financial Times (2020). Global recession is here, say top economists. Available at: https://www.ft.com/content/be732afe-6526-11ea-a6cd-df28cc3c6a68 
In each country there are workers who have been laid off and laid off without pay as a result of COVID-19. The current crisis situation may leave employers with no choice but to lay off because they have to reduce largescale operational costs. However, the Manpower Law has emphasized that layoffs should be the last step taken. Before conducting layoffs, the Manpower Law regulates how employers, laborers, trade unions, and governments must work together to prevent layoffs ${ }^{13}$.

\section{Risk of Massive layoffs}

The International Labor Organization (ILO) said the COVID-19 pandemic will affect certain groups that are vulnerable to the labor market and a decline in the number of jobs, as well as the quality of work including wages and social protection. In fact the ILO predicts that in the worst conditions there will be nearly 30 million unemployed worldwide due to this pandemic. The layoff option could be the last step to be taken. This step is a bad situation, especially for workers. Layoffs will have a very serious impact on the economy of the worker's family. On the other hand, employers are also in a difficult position because they have to fulfill obligations for employees who have been laid off.

The task of the government and us in completing the COVID-19 pandemic is still long. Rescue of citizens and suppressing the spread of the virus are the main focus at this time. We hope that the COVID-19 pandemic can be resolved immediately so that the government with the support of all parties can immediately restore the economy. The spread of Covid 19 has become one of the concerns of the community although at the beginning of the existence of this virus, various efforts in the form of appeals from the government have not really been obeyed by the community. In fact, most people assume that the virus will not be as widespread as in the country where it was originally spread ${ }^{14}$.

Various hoaxes regarding weather and climate conditions in various countries as conditions that will not cause widespread spread or hoaxes related to herbs or drugs that are considered to be able to prevent the emergence of Covid 19 turned out to be able to influence the public not to fully regard this virus as a threat ${ }^{15}$. Over time, the presence of this virus began to fret, especially when the government set a funeral protocol for people with Covid 19 which the community considered very frightening. Because it cannot be treated properly by the family. In addition, quarantine of residents who have traveled to infected areas is one of the concerns of

13 Gaiotti, E. (2013). Credit availability and investment: Lessons from the "great recession". European Economic Review, 59, 212-227.

14 Georgieva, K (2020). IMF Managing Director Kristalina Georgieva's Statement Following a G20

15 Available at:

https://www.theguardian.com/business/2020/mar/15/prepare-for-the-coronavirus-globalrecession 
the community. So now the public no longer considers this virus as an outbreak that is taken lightly.

However, along with community concerns about this virus, other impacts were found. The enactment of social distancing turned out to have other impacts. In the form of social and economic impacts in society.

\section{Avoid layoffs}

Employers, workers, trade unions and the government must be able to establish cooperation that anticipates layoffs. Here are four things you can do ${ }^{16}$ :

a. Conduct a two-way or bipartite dialogue.

Employers and workers together with trade unions need to engage in transparent dialogue early on in anticipating employment conditions due to the COVID-19 pandemic. Companies that because of their industrial nature require the presence of workers must regulate the work system by prioritizing occupational safety and health. In addition, bipartite dialogue also needs to discuss anticipation of the worst conditions of work relations between them such as efficiency, working hours arrangements, and division of labor. This dialogue is the main door to build mutual understanding to face the impact of the COVID-19 pandemic both for companies and workers.

b. Arrange employment policies in a COVID-19 pandemic situation.

This policy must respond to any changes that occur as a result of the COVID-19 pandemic towards the employee's work system. These changes include the application of the work from home system, social distancing, restrictions on public transportation facilities, and limited lockdowns that are currently being implemented by several local governments. At present there are many areas that have received approval to implement Large Scale Social Restrictions (PKB). The government, in this case the Ministry of Manpower must be active in providing policy information for work and conducting regular policy reviews. Policies that can be applied for example policies to reduce working days and hours, dismiss / lay off workers, and so on ${ }^{17}$.

In addition, the government also needs to carry out an employment mitigation plan in the face of worsening work situations due to the economic crisis as a result of the COVID-19 pandemic. This can be done by implementing government programs that can absorb a large workforce and skills development support programs such as the

16 Ministerial Call on the Coronavirus Emergency. IMF Press statement. Available at: https://www.imf.org/en/News/Articles/2020/03/23/pr2098-imf-managing-director-statementfollowing-a-g20-ministerial-call-on-the-coronavirus -emergency

17 Mian, A., \& Sufi, A. (2010). The great recession: Lessons from microeconomic data. American Economic Review, 100 (2), 51-56. 
provision of Pre-Employment Cards for people who have just graduated from school and are looking for work.

c. Realize and monitor the implementation of incentive packages for employers and workers to survive.

The government has issued incentive packages for entrepreneurs such as exempting or reducing tax payments and budget grants for the small business sector. The government itself plans to provide a stimulus of Rp 5 trillion to increase the purchasing power of cooperatives and Micro, Small and Medium Enterprises (MSMEs). In addition, social incentives are also prepared by the government for workers who are laid off or unable to work like informal sector workers. This incentive takes the form of direct assistance and discounts for the needs of facilities provided by the government (electricity and water). This policy needs to be realized and monitored so that it is right on target ${ }^{18}$.

d. Hold a three-way dialogue (tripartite) between employers, workers / trade unions and the government.

Parallel to the provision of incentive packages for employers and workers, in this difficult situation the government must also be able to mediate between the employers and workers and trade unions to prevent layoffs ${ }^{19}$. The role of the government can be sought as an intermediary in finding solutions agreed by both parties, especially related to the fulfillment of workers' rights, if layoffs are unavoidable. In this case the government can form a LAYOFFS Handling Task Force so that more responses to the problems of employers and workers during this pandemic can be anticipated and resolved early.

\section{CONCLUSION}

At present, the various social and economic impacts of social restrictions cannot be denied. The role of the central and regional government in this case becomes very important to take quick and appropriate decisions to overcome the spread of this virus. At present also, large-scale social restrictions based on regulations that have been issued can be implemented after the approval of the Minister of Health in each country which considers the large spread of the virus in an area. This needs to be re-evaluated because if a large-scale restriction is carried out after the number of infected becomes greater then it will become ineffective because the time needed to wait for the number who qualify to be given permission to apply the PKB is the same as waiting for more and more people to be infected. The implementation of PKB in all areas even though it is still in the green zone to prevent the area from becoming a red zone. A very big danger that will occur when all regions become a red zone simultaneously is the inability of the

18 Horowit, J. (2020). The global coronavirus recession is beginning. CNN. Media report. Available at:

https://edition.cnn.com/2020/03/16/economy/global-recession-coronavirus/index.html 19 Ozili, PK (2019). 100 Quotes from the Global Financial Crisis: Lessons for the future. Available 
capacity of hospitals that will bring us in conditions like in other countries where health workers will choose who has greater life potential, only that will be saved. Amidst the current COVID-19 Pandemic, some economic stimulus has been carried out by the government. However, how exactly the legal view of it.

\section{Books:}

\section{BIBILIOGRAPHY}

Bagliano, FC, \& Morana, C. (2012). The Great Recession: US dynamics and spillovers to the world economy. Journal of Banking \& Finance, 36 (1), 113.

Bentolila, S., Jansen, M., \& Jiménez, G. (2018). When credit dries up: Job losses in the great recession. Journal of the European Economic Association, 16 (3), 650-695.

Bezemer, DJ (2011). The credit crisis and recession as a paradigm test. Journal of Economic Issues, 45 (1), 1-18.

El-Erian, M. (2020). The Coming Coronavirus Recession and the Uncharted Territory Beyond.

Gaiotti, E. (2013). Credit availability and investment: Lessons from the "great recession". European Economic Review, 59, 212-227.

Georgieva, K (2020). IMF Managing Director Kristalina Georgieva's Statement Following a G20

Jagannathan, R., Kapoor, M., \& Schaumburg, E. (2013). Causes of the great recession of 2007 ?? 2009: The financial crisis was the symptom not the disease. Journal of Financial Intermediation, 22 (1), 4-29.

Larry Elliot, L. (2020). Prepare for the coronavirus global recession. The Guardian. Media report.

\section{Internet:}

2020. Worldometer. Available: https://www.worldometers.info/coronavirus/. HOROWITZ, CRAJ 2010. The coronavirus is already hurting the world economy. Here's why it could get really scary. CNNBUSINESS, February 10, 2020.HUTT, R. 2020. The economic effects of the COVID-19 coronavirus around the world. The World Economic Forum.INMAN, P. 2020a. Coronavirus 'could cost global economy \$1.1tn in lost income'. The Guardian, Wed 19 Feb 2020.INMAN, P. 2020b. Will the coronavirus outbreak derail the global economy? The Guardian. International Review of Finance, 10 (1), 1-26. 
Foreign Affairs, Media Report. Available at: https://www.foreignaffairs.com/articles/2020-03- 17 / coming-coronavirusrecession

Financial Times (2020). Global recession is here, say top economists. Available at: https://www.ft.com/content/be732afe-6526-11ea-a6cd-df28cc3c6a68

Ministerial Call on the Coronavirus Emergency. IMF Press statement. Available at: https://www.imf.org/en/News/Articles/2020/03/23/pr2098-imf-managingdirector-statement-following-a-g20-ministerial-call-on-the-coronavirus emergency

Horowit, J. (2020). The global coronavirus recession is beginning. CNN. Media report. Available at: https://edition.cnn.com/2020/03/16/economy/globalrecession-coronavirus/index.html

Available at: https://www.theguardian.com/business/2020/mar/15/prepare-forthe-coronavirus-global-recession 